\title{
РАЦІОНАЛЬНА ОРГАНІЗАЦІЯ КОСМЕТОЛОГІЧНОГО ДОГЛЯДУ ЗА ШКІРОЮ ПАЦІЄНТІВ ІЗ ВУГРОВОЮ ХВОРОБОЮ З УРАХУВАННЯМ РОЛІ СТРЕСОВОГО ЧИННИКА
}

\author{
М. В. Байбарак \\ Тернопільський національний медичний університет \\ імені І. Я. Горбачевського МОз Украӥни
}

У статті проаналізовано поширеність вугрової хвороби та вплив стресу на стан шкіри.

\section{RATIONAL ORGANIZATION OF COSMETIC SKIN CARE OF PATIENTS WITH ACNE, TAKING INTO ACCOUNT THE ROLE OF STRESS FACTOR}

\author{
M. V. Baybarak
}

\section{Horbachevsky Ternopil National Medical University}

The article analyzes the prevalence of acne and the impact of stress on skin condition.

Вступ. Загострення вугрової хвороби провокують розмаїті чинники зовнішнього і внутрішнього середовища організму, зокрема забруднення навколишнього середовища, агресивні косметичні середники, медикаменти, механічні пошкоджувальні впливи, спадковість, стиль життя і стресовий чинник $[1,3,6]$. У сучасному суспільстві набирають значення агресивні провокуючі чинники зовнішнього середовища екологічні забруднення, тютюновий дим, оксиди і поліциклічні ароматичні вуглеводневі сполуки, агресивні органічні середники, які виявляють у повітрі населених міст, ультрафіолетове випромінювання.

Основна частина. За даними наукової літератури, шкірні захворювання $\epsilon$ як наслідком, так і причиною сильного емоційного стресу, зниження самооцінки та незадоволеності життям [4]. Дослідження «випадок контроль», популяційні та когортні дослідження за участю пацієнтів із вугровою хворобою свідчать, що ця хвороба провокує виражені психосоціальні порушення та стрес. Також було проведено поперечне скринінгове дослідження, у рамках якого, за результатами стандартизованого питання, виявили ознаки дисморфобії у пацієнтів, які страждали від вугрової хвороби та потребували психологічної підтримки. Було встановлено, що у частини пацієнтів () М. В. Байбарак, 2019
(14,1-21,2 \%) спостерігали заклопотаність та тривогу відносно зовнішнього вигляду шкіри обличчя. Відомо, що на фоні стресу змінюється проникність шкірного бар'єра, погіршується захисна функція шкіри. Також дослідження показали, що глюкокортикоїди, що виробляються в організмі при впливі стресу, інгібують утворення ліпідів, тим самим пригнічуючи синтез та секрецію ламелярних тіл, та погіршують захисну функцію шкіри $[1,2]$. Таким чином, психологічний стрес здатен погіршити та навіть ініціювати різноманітні захворювання та патологічні стани шкіри, у тому числі псоріаз та атопічний дерматит.

Особливості функціонального і психологічного стану клієнтів спонукають косметолога організувати догляд на засадах підходу, центрованого на проблемах пацієнта. Надзвичайно важливого значення тут набирає професійна етика. Зокрема сучасна персоналістична модель медичної біоетики пропонує вважати за найвищу цінність життя і здоров'я пацієнта, принциповим питанням $є$ також повага до прав і гідності пацієнта, захист його автономії.

На практиці у створенні сприятливого середовища у косметичному кабінеті має значення усе, починаючи від акуратного зовнішнього вигляду і ввічливої манери спілкування косметолога. Якщо фахівець викликає довіру, клієнт звернеться у косметичний кабінет зно- 
ву. Повага до прав пацієнта вимагає пояснити, які методи догляду пропонує косметолог, які ефекти (разом із їх побічною дією і ризиком застосування) очікують від кожного методу. Автономія пацієнта означає, що остаточний вибір косметичної процедури здійснює пацієнт, а етичний обов'язок косметолога правдиво і в достатньому обсязі проінформувати щодо можливих методів догляду і їх реальної ефективності. Сучасний біоетичний підхід вимагає від косметолога ґрунтовних професійних знань у поєднанні з розвинутими комунікативними навичками і порядністю. Окремо варто зауважити про захист приватної інформації пацієнта. Надання догляду має здійснюватись індивідуально. Приватна інформація пацієнта, яка потрібна косметологу для планування догляду, не повинна поширюватись за межі косметичного кабінету. Документація, яка містить приватні дані пацієнта, має бути захищена від доступу третіх осіб, адже вся процедура догляду $\epsilon$ таємницею між косметологом і пацієнтом.

Методи догляду за шкірою, які пропонує косметолог, потрібно обирати на основі доказових наукових досліджень, які можна знайти у сучасних наукових публікаціях. Необхідно пам'ятати, що шкіра людини - це орган, який бере участь у диханні, терморегуляції, обмінних і багатьох інших процесах. Шкіра $\epsilon$ масивним полем різних видів рецепторної чутливості. Незважаючи на те, що взаємозв'язок між стресом та погіршенням перебігу захворювань шкіри вивчений недостатньо, на сьогодні вже сформульовано дві гіпотези, які пояснюють цей зв'язок.

В організмі хворих спостерігають активацію двох гормонально опосередкованих систем стресу: гіпоталамо-гіпофізарно-надниркової системи, активація якої супроводжується збільшенням концентрації кортизолу, і симпатичної нервової системи, активація якої супроводжується збільшенням вироблення адреналіну [4]. Відповідно до гіпотези, саме ці дві системи стресу впливають на імунний баланс в організмі та сприяють запальним процесам у шкірі. Існує також думка, що периферичні нейропептидергічні нервові волокна здатні передавати стимули шкіри, підсилюючи запальні процеси. У ході експерименту на мишах дослідники відзначили, що кількість шкірних нервових волокон, які містять стресорний нейропептид (речовину Р), істотно збільшувалась при стресі та ато- пічному дерматиті. Клінічно це проявлялося у вигляді нейрогенного запалення шкіри, зокрема локального збільшення концентрації цитокінів, які $є$ мішенню для патогенетичної терапії.

Завдяки опису третьої системи стресу стало можливим розробити принципово нові підходи до лікування хвороб та патологічних станів шкіри, зумовлених стресом. Перед виконанням будь-яких косметологічних маніпуляцій рекомендують зробити скринінг, покликаний з'ясувати емоційну реакцію людини на зовнішній вигляд своєї шкіри. При обстеженні та лікуванні більшості пацієнтів у дерматологічній практиці необхідно брати до уваги психосоціальні чинники, наявність сімейних захворювань, гормональних розладів [5]. Більш того, виявлення супутньої патології в багатьох випадках може розглядатися як протипоказання до косметологічного лікування, до повної компенсації патологічної симптоматики. За потреби клієнту можна рекомендувати звернутися до ендокринолога, невропатолога, психолога тощо.

Висновки. Оскільки зовнішність людини має вплив на соціальну їі адаптацію у сучасному суспільстві, більшість звертається до фахівців з індустрії краси та до лікарів-дерматологів і хірургів з метою поліпшення зовнішності за допомогою різноманітних маніпуляцій. Косметологи, дерматологи та пластичні хірурги повинні допомогти людині не просто виглядати молодшою, а й стати здоровішою, наблизитися через догляд за власною зовнішністю до стану найкращого фізичного, духовного й інтелектуального благополуччя.

Косметолог повинен нести відповідальність за кожне прийняте рішення і керуватися головним принципом деонтології «Не нашкодь!». При легкій формі захворювання, що проявляється лише камедонами та невеликою кількістю запалених висипань, косметолог може вирішити проблему самостійно. При середньому і тяжкому ступенях вугрової хвороби, коли спостерігають виражені запальні реакції, косметолог має діяти спільно з лікарем-дерматологом, який призначить індивідуальне лікування. Для оцінки ефективності косметологічного догляду, окрім огляду і отримання відгуку пацієнта про якість наданих косметологічних процедур, доцільно застосовувати об'єктивні методи оцінки стану шкіри, як, наприклад, дерматоскопія. 


\section{СПИСОК ЛІТЕРАТУРИ}

1. Bashour M. History and current concepts in the analysis of facial attractiveness. - Plast Reconstr Surg. - 2006. Vol. 88. - P. 741.

2. Chiu A. The response of skin disease to stress: changes in the severity of acne vulgaris as affected by examination stress / A. Chiu, S. Y. Chon, A. B. Kimball // Archives of Dermatology. - 2003. - Vol. 139 (7). - P. 897-900.

3. Ghodsi S. Z. Prevalence, severity, and severity risk factors of acne in high school pupils: a community-based study / S. Z. Ghodsi, H. Orawa, C. C. Zouboulis // The Journal of Investigative Dermatology. - 2009. - Vol. 129 (9). P. 2136-2141.
4. Psychoneuroimmunologic aspects of skin diseases / L. Lugovic-Mihic, L. Ljubesic, J. Mihic [ et al.] // Acta clinica Croatica. - 2013. - Vol. 52 (3). - P. 337-345.

5. Melnik B. C. Potential role of FoxO1 and mTORC1 in the pathogenesis of Western diet-induced acne / B. C. Melnik, C. C. Zouboulis // Experimental Dermatology. - 2013. Vol. 22 (5). - P. 311-315.

6. Effects of air pollution on the skin: A review / P. Puri, S. K. Nandar, S. Kathuria, V. Ramesh // Indian Journal of Dermatology, Venereology and Leprology. - 2017. Vol. 83 (4). - P. 415-423.

Отримано 23.08.19 